Article

\title{
Pectin-Based Films Loaded with Hydroponic Nopal Mucilages: Development and Physicochemical Characterization
}

\author{
Brenda Luna-Sosa ${ }^{1}$, Guillermo C.G. Martínez-Ávila ${ }^{1}$, Humberto Rodríguez-Fuentes ${ }^{1}$, \\ Ana G. Azevedo ${ }^{2}$, Lorenzo M. Pastrana ${ }^{2}$, Romeo Rojas ${ }^{1}(\mathbb{D})$ and Miguel A. Cerqueira ${ }^{2, *(D)}$ \\ 1 Research Center and Development for Food Industries, School of Agronomy, \\ Universidad Autónoma de Nuevo León, General Escobedo 66050, Nuevo León, Mexico; \\ tecadnerb@gmail.com (B.L.-S.); guillermo.martinezavl@uanl.edu.mx (G.C.G.M.-Á.); \\ hrodrigu10@yahoo.com.mx (H.R.-F.); romeo.rojasmln@uanl.edu.mx (R.R.) \\ 2 International Iberian Nanotechnology Laboratory, Av. Mestre José Veiga s/n, 4715-330 Braga, Portugal; \\ ana.azevedo@inl.int (A.G.A.); lorenzo.pastrana@inl.int (L.M.P.) \\ * Correspondence: miguel.cerqueira@inl.int
}

Received: 17 April 2020; Accepted: 6 May 2020; Published: 10 May 2020

check for

\begin{abstract}
Nopal is a potential source of mucilage that can be used in different food applications. One of its potential use is the development of films and coatings where it can act as a packaging material but also as a source of bioactive compounds. Therefore, this work aimed to develop and characterize pectin-based films loaded with mucilage extracted from two species of nopal, Copena F1 (Cop) and Villanueva (Vi). The obtained mucilages were denominated as materials without fibre (Copwtf and Viwtf) and with fibre (Copwf and Viwf), according to the fibre's size. Films were produced with pectin $(2 \% w / v)$, mucilage $(2.5 \% w / v)$ and glycerol $(0.5 \% w / v)$ by the casting method. The addition of mucilages was shown to influence the visual appearance, optical properties and morphology of the films. The presence of mucilage also changed the moisture content, water contact angle and water vapour permeability of the films. The pectin-based films without mucilage presented the best mechanical properties. Fourier-transform infrared (FTIR) spectroscopy showed similar signals in terms of frequency and intensity, for all the films, not showing any chemical modification. Results show that the mucilage obtained from different nopal fractions can be used in pectin-based films foreseeing their use as films or coatings in food applications.
\end{abstract}

Keywords: edible films; edible coatings; mucilages; fibres; hydroponics; bioactive compounds

\section{Introduction}

Films and coatings industries have generated a remarkable growth in recent years, specifically in the preservation of perishable food products. This growth is followed by the increasing interest in replacing synthetic polymers currently used by bio-based polymers and biodegradable polymers [1-5]. There are already several studies about films and coatings produced by bio-based polymers, such as polysaccharides, proteins and lipids, where they have been used on the preservation of food products. The performance of these films and coatings is directly influenced by chemical characteristics, production method, concentration and environmental conditions in which it is produced [6]. Another of the challenges is to use bio-based and biodegradable polymers obtained from subproducts and/or agricultural waste, in order to reduce food waste and make agriculture more sustainable.

Recently, in Mexico, some studies were carried out using nopal cactus (Opuntia ficus-indica), subproducts generated by the plant, as a source of bioactive compounds for food and nutrition [7]. 
Due to their overproduction, about $20 \%$ of nopal crop is wasted, and the use of this subproduct in high-value agro-industrial applications is of high interest.

Mucilages are one of the examples of subproducts resulting from agricultural wastes from nopal. They are characterized by being hydrocolloids of long chains and high molecular weight mainly constituted by proteins $(\approx 11 \%)$ and carbohydrates $(\approx 47 \%)$, and where the carbohydrates are composed by monosaccharides, such as arabinose (11.60), galactose (20.84), glucose (4.50), xylose (6.64), galacturonic acid (0.18) and glucuronic acid (15.22 g/100 g of dry matter of mucilage) [8]. These components are related to the species, age and type of nutrition of the plant. Additionally, these polysaccharides present minerals in a crystallized form [9]. Mucilages also present the microelements iron $(189.7 \mathrm{mg} / 100 \mathrm{~g})$, manganese $(175.20 \mathrm{mg} / 100 \mathrm{~g})$, zinc $(93.30 \mathrm{mg} / 100 \mathrm{~g})$, and calcium $(3.35 \mathrm{mg} / 100 \mathrm{~g})[10,11]$. In addition, the mucilage contains a fibrous material $(30 \%-40 \%)$ that can be found in a soluble or insoluble state depending on physiology and age of the plants. Soluble fibres have the effect of stimulating cholesterol catabolism due to its calcium content and, therefore, can be used as a functional ingredient.

Villanueva (Vi) and Copena F1 (Cop) are two species of nopal (or Opuntia ficus-indica) cultivated in Mexico which are used as a fruit, vegetable and fodder. Copena F1 produces long, thin and green sprouts and is considered a vegetable-purpose. This culture was developed in the College of Postgraduates-National School of Agriculture, Chapingo, Mexico [12]. Villanueva has a longitudinal semicircular shape and culture and was from Zacatecas. It is considered as a triple-purpose culture, that is, for the production of prickly pears, as vegetables for human consumption, and as fodder for cattle [13]. In general, the mucilages extracted from Vi and Cop can be used for some applications in the food area, pharmaceutical, construction and cosmetic, due to the availability, abundance and low cost.

These mucilages have caught attention in the food industry, namely for the production of films and coatings, where they can be used to extend the shelf life of perishable products (such as fruits) before, during and after harvesting. However, to produce films using mucilage it is normally required to employ a polymer and a plasticizer that can be used to improve its processability. One of the possibilities is pectin that due to its similar composition is an appropriate polymer to be incorporated in films based on nopal mucilage. Some features of pectin include the formation of gels when the homogalacturonan is cross-linked to form a three-dimensional network in an aqueous medium. The gelling properties of pectin are determined by factors such as the degree of esterification of methyl, degree of acetylation, temperature, $\mathrm{pH}$, sugar and calcium [14]. Concerning the plasticizers, there is a study in which the physicochemical properties of mucilage films of Opuntia spp. were tested with several types of plasticizers (polyols and glycerol) [15]. The study showed that the effect of the addition of polyol-type plasticizers influence the properties of mucilage-based films since they generated interactions in functional groups and thermal characteristics. In addition, Torres et al. [16] formulated films of Opuntia ficus-indica mucilage with the addition of chitosan and active ingredients extracted from ornamental plants. They concluded that the studied films could be useful to extend the shelf life of fruits from Capsicum annuum var. Serrano under both refrigeration and room temperature conditions. Also, Del Valle et al. [17] and Treviño-Garza et al. [18] studied the effect of edible coating of mucilage extracted from Opuntia ficus-indica on the shelf-life of strawberries. The results disclosed that edible coating increased shelf-life under controlled conditions. Recently, Abirami et al. [19], Allegra et al. [20], Cortés et al. [21], Jouki et al. [22], Allegra et al. [23], Soukoulis et al. [24], Beigomi et al. [25], Sadhegi et al. [26], Natália et al. [10] and Minna et al. [27] studied the effect of coatings produced with mucilages extracted from different plants on the shelf-life of fruits.

However, to the best of the authors' knowledge, there is no evidence of the effect of fibres' size from different types of mucilage, on the physicochemical properties and morphological characteristics of pectin-based films. Therefore, this work aimed to produce films based on mucilage extracted from the Villanueva and Copena F1 nopals with a state of maturity of 45 days cultivated in a hydroponic system and to compare the morphology, physical and mechanical properties with the control film 
(pectin and glycerol). In addition, the films were evaluated by Fourier-transform infrared (FTIR) spectroscopy and X-ray diffraction.

\section{Materials and Methods}

\subsection{Materials}

Mucilage powder was extracted from Copena F1 (Cop) and Villanueva (Vi) without and with fibres (designation Copwtf, Copwf, Viwtf and Viwf, respectively). Mucilage powders were extracted from nopal (obtained from the School of Agronomy, Campus Marín, Universidad Autónoma de Nuevo León) with a state of maturity of 45 days from a hydroponic system as presented elsewhere [28,29] with some modifications. The dried mucilages were then sieved in a sieve of $\varnothing 0.75 \mathrm{~mm}$ and $\varnothing 1.75 \mathrm{~mm}$ (MEQUIM, Lima, Peru) and denominated mucilage without fibres (Copwtf and Viwtf) and with fibres (Copwf and Viwf), respectively. The samples were stored in an airtight container until use. Pectin from citrus peel (galacturonic acid of $\geq 74.0 \%$ of dried basis) used as base polymer and glycerol $(\geq 99.5 \%)$ used as plasticizer were purchased from Sigma Aldrich (St. Louis, MO, USA).

\subsection{Film Preparation}

Pectin $(2.0 \% w / v)$ was dissolved in distilled water with constant stirring during $1 \mathrm{~h}$ at $23{ }^{\circ} \mathrm{C}$, after total dissolution 2.5\% (w/v) of mucilage powders (Copwf, Viwf, Copwtf and Viwtf) were mixed and stirred a further $2 \mathrm{~h}$. Afterwards, glycerol was added in the final concentration of $0.5 \%(w / v)$ and stirred until all mixture was dissolved. This formulation (i.e., concentrations and mixing procedure) was selected based on previous studies where the aim was to add the maximum amount of mucilage powders to the pectin matrix and maintain good film processability. Then, $15 \mathrm{~mL}$ of film-formation solution was cast into polystyrene Petri dishes and dried at $45^{\circ} \mathrm{C}$ during $24 \mathrm{~h}$. Films were conditioned at $54 \% \pm 1 \%$ relative humidity $(\mathrm{RH})$, and $20 \pm 1{ }^{\circ} \mathrm{C}$ by placing them in a desiccator container a saturated solution of $\mathrm{Mg}\left(\mathrm{NO}_{3}\right)_{2} \mathrm{H}_{2} \mathrm{O}$. Film with $2.0 \%(w / v)$ pectin and $0.5 \%(w / v)$ glycerol was called the control film.

\subsection{Films' Characterization}

\subsubsection{Optical Properties}

Optical measurements were performed according to the reported by Martins et al. [30] using a Minolta colourimeter (Minolta CR 400, Tokyo, Japan). The CIELab scale was used to determine $L^{*}, a^{*}$ and $b^{*}$ parameters. Standard values considered were those of a white background $\left(L^{*}=84.67\right.$, $a^{*}=-0.55$, and $b^{*}=0.68$ ). The opacity of the mucilage films indicated the amount of light that passed through the materials and were determined according to the Hunterlab method, as the relationship between the opacity of each sample on a white standard. Six measurements were made of each sample, and three samples of each treatment were tested.

\subsubsection{Scanning Electron Microscopy (SEM)}

The surface (air dried side) morphologies of films were examined using scanning electron microscopy (SEM) (Quanta FEG 650, FEI, Hillsboro, OR, USA) with an accelerating voltage of $5 \mathrm{kV}$. Before analysis, all samples were mounted on aluminium stubs using carbon adhesive tape and sputter-coated with gold.

\subsubsection{Thickness}

A digital micrometre (No. 293-340, Mitutoyo, Kanagawa, Japan) was used to measure the film thickness measurements. Five thickness measurements were randomly taken on each film sample and the average was used to calculate water vapour permeability and tensile strength. 


\subsubsection{Moisture Content (MC) and Water Solubility (WS)}

The MC was expressed as the percentage of water removed from the initial mass sample. MC was determined gravimetrically by drying film samples (about $50 \mathrm{mg}$ ) at $105^{\circ} \mathrm{C}$ in an oven with forced air circulation for $24 \mathrm{~h}$. The experiments were performed on each film sample in triplicate.

The solubility was carried out in quadruplicate, based on the method proposed by Casariego et al. [31]. After drying at $105^{\circ} \mathrm{C}$ during $24 \mathrm{~h}$, the films (disks with $2 \mathrm{~cm}$ in diameter) were weighed and immersed into $50 \mathrm{~mL}$ of Mili-Q water and placed in an orbital shaker under stirring for $24 \mathrm{~h}$ at $20^{\circ} \mathrm{C}$. The films were inspected by the naked eye every hour to determine the time until complete solubility. The films were considered soluble after the total disintegration of the films in the solution.

\subsubsection{Water Contact Angle (WCA)}

The water contact angle $(\theta)$ was determined by the sessile drop technique using a DSA 100E drop shape analysis system (Kruss Gmbh, Hamburg, Germany). A water droplet ( $2 \mathrm{uL}$ ) was deposited in different points of the film surface (air-dried side), and afterwards a digital camera connected to DSA 3 drop shape image analysis software recorded drop images. The image produced was used to calculate the contact angle via the Laplace-Young fitting method. Three replicated measurements of $\theta$ (upper surface of the film) were obtained.

\subsubsection{Water Vapour Permeability (WVP)}

Water vapour permeability (WVP) was determined gravimetrically using the ASTM E96-92 method [32] described by Casariego et al. [31]. Three samples were cut from each film. Each film sample was sealed on a permeation cell containing distilled water $\left(100 \% \mathrm{RH} ; 2.337 \times 10^{-3} \mathrm{~Pa}\right.$ vapour pressure at $\left.20{ }^{\circ} \mathrm{C}\right)$, and placed in a desiccator containing silica gel $\left(0 \% \mathrm{RH} ; 20^{\circ} \mathrm{C}\right)$. The cells were weighted at $2 \mathrm{~h}$ intervals during $10 \mathrm{~h}$. The slope of weight loss versus time was obtained by linear regression. The measured (WVP) of the films was determined as follows:

$$
W V P=\left[\frac{W V T R \cdot L}{\Delta P}\right]
$$

where WVTR in the measured water vapour transmission rate through a film, $L$ is the mean film thickness $(\mathrm{m})$, and $\Delta P$ is the partial water vapour pressure difference (Pa) across the two sides of the film. The experiments were performed in triplicate for each mucilage film.

\subsubsection{Mechanical Properties}

Tensile strength (TS), Young's modulus (YM) and elongation-at-break (EB) were determined with a texture analyzer (TA-HD plus, Stable Micro System, Godalming, UK) using ASTM D 882-91 [33] described by Ricardo et al. [34]. Films $(120 \mathrm{~mm} \times 20 \mathrm{~mm})$ were cut from each preconditioned $(54 \% \mathrm{RH})$. The initial grip separation and crosshead speed were set to $100 \mathrm{~mm}$ and $5 \mathrm{~mm} \cdot \mathrm{min}^{-1}$, respectively. At least seven replications of each film were performed.

\subsubsection{X-ray Diffraction (XRD)}

The X-ray diffractometer X Pert PRO MRD from Malvern Panalytical Ltd. (Royston, UK) was used for XRD analysis during the different time-points. X-ray scans were done at room temperature $\left(\sim 22^{\circ} \mathrm{C}\right)$ in the range of $10^{\circ}$ to $50^{\circ}$ ( $2 \theta$ degrees), using a Cu source, $X$-ray tube $(\gamma=1.54056 \AA)$ at $45 \mathrm{kV}$ and $40 \mathrm{~mA}$ with $\theta$ set to -0.0372 degrees for fine calibration offset.

\subsubsection{Fourier Transform Infrared (FTIR) Spectroscopy}

FTIR spectra of the films were recorded with a Bruker FT-IR VERTEX 80/80v (Boston, MA, USA) in attenuated total reflectance mode (ATR) with a platinum crystal accessory in the wavenumber range: 
$4000-400 \mathrm{~cm}^{-1}$, using 16 scans at a resolution of $4 \mathrm{~cm}^{-1}$. Before analysis, an open bean background spectrum was recorded as a blank. All measurements were performed in triplicate.

\subsubsection{Thermal Analysis}

The thermal stability and degradation of the films were analyzed by the thermogravimetric analysis (TGA), performed with a simultaneous thermal analyzer and a differential scanning calorimeter (TGA/DSC 3+, Mettler Toledo, Palatine, IL, USA). Samples ( $\approx 5 \mathrm{mg}$ ) were heated from 20 to $500{ }^{\circ} \mathrm{C}$ at a heating rate of $10^{\circ} \mathrm{C} \mathrm{min}^{-1}$ under a nitrogen atmosphere to avoid thermo-oxidative reactions.

\subsection{Statistical Analysis}

Statistical analysis was performed using analysis of variance (ANOVA) with a 95\% confidence level using Vassarstats (http://vassarstats.net).

\section{Results and Discussion}

\subsection{Visual Appearance and Optical Properties}

The films obtained were homogeneous with a uniform and compact structure, suggesting the proper incorporation of mucilages into pectin matrix, as can be seen in Figure 1. However, the fibres are visible in films with Copena F1 and Villanueva with fibre (Figure 1C,E), while for films using mucilage without fibre is only visible a colour variation (Figure 1A,D). This difference is explained by the different fibre sizes obtained after sieving, where those sieved in a sieve at $\varnothing 1.75 \mathrm{~mm}$ had a higher visual influence on the films.
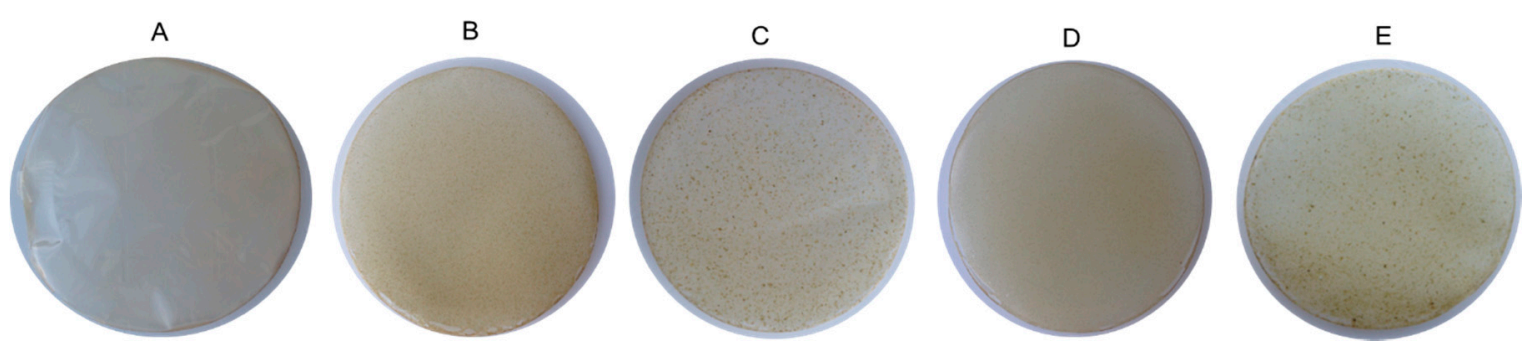

Figure 1. Pictures of the films: (A) control (Pectin) (Ctrl), (B) Copena F1 without fibre (Copwtf), (C) Copena F1 with fibre (Copwf), (D) Villanueva without fibre (Viwtf) and (E) Villanueva with fibre (Viwf).

The presence of mucilage has a significant influence on the optical properties of the films. Table 1 presents the CIELab parameters and opacity values for the produced films. The films Copwtf $(6.21 \%)$ and Viwtf (6.39\%) showed the highest opacity values. On the other hand, films with fibres (Copwf and Viwf) reached values of $3.23 \%$ and $3.92 \%$ presenting lower $(p<0.05)$ opacity values than the control films $(4.38 \%)$. These results show that the addition of mucilage with higher size fibres decreases the opacity values.

Table 1. Optical properties and opacity of Copena F1 without fibre (Copwtf), Copena F1 with fibre (Copwf), Villanueva without fibre (Viwtf) and Villanueva with fibre (Viwf) films.

\begin{tabular}{ccccc}
\hline Film Samples & $\boldsymbol{L}^{*}$ & $\boldsymbol{a}^{*}$ & $\boldsymbol{b}^{*}$ & Opacity (\%) \\
\hline Control & $99.19 \pm 0.22 \mathrm{a}$ & $15.50 \pm 0.60 \mathrm{a}$ & $13.86 \pm 1.36 \mathrm{a}$ & $4.38 \pm 0.32 \mathrm{a}$ \\
Copwtf & $82.90 \pm 0.14 \mathrm{~d}$ & $0.96 \pm 0.12 \mathrm{~d}$ & $18.09 \pm 1.13 \mathrm{~b}$ & $6.21 \pm 0.24 \mathrm{~b}$ \\
Copwf & $88.43 \pm 1.94 \mathrm{e}$ & $0.05 \pm 0.03 \mathrm{c}$ & $13.11 \pm 1.57 \mathrm{a}$ & $3.92 \pm 0.09 \mathrm{~d}$ \\
Viwtf & $69.22 \pm 0.65 \mathrm{~b}$ & $3.29 \pm 0.43 \mathrm{~b}$ & $28.43 \pm 1.07 \mathrm{c}$ & $6.39 \pm 0.05 \mathrm{~b}$ \\
Viwf & $92.60 \pm 1.22 \mathrm{c}$ & $0.07 \pm 0.02 \mathrm{c}$ & $15.91 \pm 2.83 \mathrm{ab}$ & $3.23 \pm 0.02 \mathrm{c}$ \\
\hline
\end{tabular}

Values reported are the mean \pm standard deviation (sd). Different letters (a-d) in the same column indicate a statistically significant difference $(p<0.05)$. 
Control films present the highest luminosity $\left(L^{*}\right)$ values (99.19), while the lowest values were obtained for the films of Viwtf (69.22). This variation is in agreement with the opacity values of the films. The results show that the sieving process, besides sieving the different sized fibres, also influenced the film composition and thus influenced the opacity values. The difference in the mucilage structures after sieving can be related to their final composition, where the ratio between materials is changed.

The Viwtf film presents a high yellow profile $\left(b^{*}=28.43\right)$ that is followed by the brown colour observed in Figure 1, while for the other films is observed a slight beige tone due resulting in values ranged between 13.86 and 18.09. The red coordinates $\left(a^{*}\right)$ were more pronounced in Ctrl and Viwtf films (15.50, 3.29, respectively).

The values obtained are in agreement with Luo et al. [27] and Gheribi et al. [15] that determined the luminosity of the films with mucilages and obtained values ranged between 86.72 to 93.05 . By contrast, Oliveira et al. [35] estimated $L^{*}$ values from 21.94 to 24.02 of films with mucilages of Pereskia aculeata Miller, lower than the values presented in this work.

\subsection{Scanning Electron Microscopy (SEM)}

Figure 2 shows the SEM images of surfaces of the films that appeared without pores and cracks. The Ctrl film presented a smooth and continuous surface that is explained by a good homogeneous mixture attributed to the polymer-plasticizer compatibility.

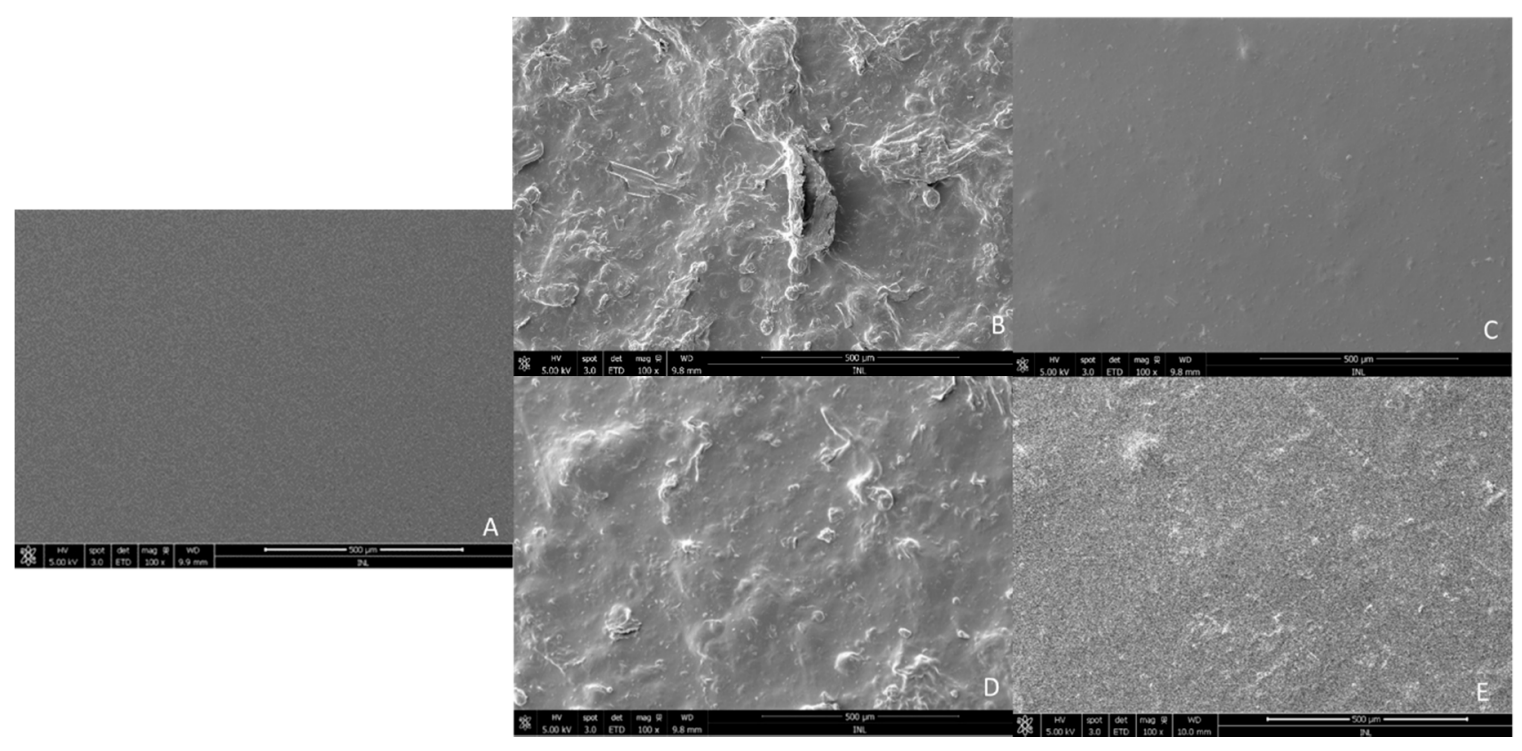

Figure 2. Scanning electron microscopy (SEM) images of surfaces of the edible films. (A) Control, (B) Copena F1 without fibre (Copwtf), (C) Copena F1 with fibre (Copwf), (D) Villanueva without fibre (Viwtf) and (E) Villanueva with fibre (Viwf) (100× magnification) (scale bar corresponds to $500 \mu \mathrm{m})$.

The films without fibre present a similar aspect. In the case of Copwtf (Figure 2B), a more heterogeneous structure is observed. However, it is clear for both cases, that the sieving process has increased the soluble material presented in the mucilage, added to the films. This behaviour can be explained by the difference in the mucilage structures after sieving. In the case of films with mucilages with a sieving process using a higher size $(\varnothing 1.75 \mathrm{~mm})$, the structures look smaller and with more space, which can be explained by the larger size of the fibres (Figure 2C,E). This is in agreement with opacity values where a more compact structure decreased the light that passes by the films and, therefore, the films of Copwf and Viwf presented the lowest opacity values. Likewise, Lira-Vargas et al. [36] state that films made with mucilages of Opuntia spp. are lumpy, independent of the variety used, since they contain dispersed granules making their structure discontinuous. 


\subsection{Thickness, Moisture Content (MC), Water Contact Angle (WCA) and Water Solubility (WS)}

The films' thickness is presented in Table 2 and shows that the incorporation of mucilages increased the thickness of most of the films. The Ctrl film presented a value of $0.08 \mathrm{~mm}$ that is statistically similar to the values obtained for Viwtf, however, for Viwf, Copwf and Copwtf, there is a significant increase $(p<0.05)$ in the values. This increase is more pronounced for the films with Copena mucilages, and is justified by the increasing amount of solids of films with mucilage. Also, the presence of fibres influenced the thickness values leading to a statistically significant $(p<0.05)$ increase for Copwf films values $(0.22 \mathrm{~mm})$ when compared with Copwtf films values $(0.17 \mathrm{~mm})$.

Table 2 shows that the control film presents the lower MC values and that the presence of mucilages in the films leads to an increase of MC. This behaviour can be explained by hydrophilic groups of mucilage that present more affinity to water molecules. The films produced with Cop, without and with fibre, presented similar values (12.41\% and $12.44 \%$, respectively), not showing any effect of the presence of the fibres on the MC values. Concerning the films with Vi mucilages without and with fibres, the behaviour is different. Viwtf films showed a higher moisture content (13.18\%) since it probably had a higher affinity with highly hydrophilic compounds in their matrix resultant of the presence of the fibres.

Table 2. Thickness, moisture content (MC), water contact angle (WCA) and water vapour permeability (WVP) of Copena F1 without fibre (Copwtf), Copena F1 with fibre (Copwf), Villanueva without fibre (Viwtf) and Villanueva with fibre (Viwf) films.

\begin{tabular}{ccccc}
\hline Film Samples & Thickness $(\mathbf{m m})$ & MC $(\mathbf{\%})$ & WCA $\left(^{\circ}\right)$ & WVP $\left(\times \mathbf{1 0}^{-\mathbf{1 1}} \mathbf{g}(\mathbf{m} \cdot \mathbf{s} \cdot \mathbf{P a})^{\mathbf{- 1}}\right)$ \\
\hline Control & $0.08 \pm 0.01 \mathrm{a}$ & $8.85 \pm 0.06 \mathrm{a}$ & $87.22 \pm 6.02 \mathrm{a}$ & $10.05 \pm 1.16 \mathrm{a}$ \\
Copwtf & $0.17 \pm 0.03 \mathrm{c}$ & $12.41 \pm 0.08 \mathrm{~d}$ & $37.80 \pm 7.57 \mathrm{~b}$ & $44.28 \pm 4.68 \mathrm{c}$ \\
Copwf & $0.22 \pm 0.03 \mathrm{~d}$ & $12.44 \pm 0.01 \mathrm{~d}$ & $39.32 \pm 8.75 \mathrm{~b}$ & $20.95 \pm 2.60 \mathrm{~d}$ \\
Viwtf & $0.11 \pm 0.05 \mathrm{ab}$ & $13.18 \pm 0.02 \mathrm{~b}$ & $37.12 \pm 9.92 \mathrm{~b}$ & $33.83 \pm 5.65 \mathrm{~b}$ \\
Viwf & $0.15 \pm 0.06 \mathrm{bc}$ & $9.29 \pm 0.01 \mathrm{c}$ & $39.89 \pm 5.74 \mathrm{~b}$ & $26.96 \pm 0.47 \mathrm{bd}$ \\
\hline
\end{tabular}

Values reported are the mean $\pm \mathrm{sd}$. Different letters $(\mathrm{a}-\mathrm{d})$ in the same column indicate a statistically significant difference $(p<0.05)$.

Sadhegi et al. [26] also produced films with mucilage extracted from Lallemantia iberica seeds at a concentration of $1.2 \%$ and glycerol (35\%) and reported a MC value of $19.86 \%$, which are higher than the values obtained in this work. Beigomi et al. [25] produced mucilage films obtained from Dracocephalum moldavica seeds using glycerol concentrations varying from $10 \%$ to $40 \%$ and obtained MC values of $16.40 \%$ to $27.06 \%$, respectively. The variations observed can be explained by plasticizers and the different mucilages used, but also by the different concentrations of the polymers used during their formulation.

The CA values are shown in Table 2. The Ctrl film showed the highest water contact angle values $\left(87.22^{\circ}\right)$ when compared with films with mucilage. The high degree of esterification of methoxyl of pectin can leads to a hydrophobic surface. The mucilages added in the films significantly decreased the contact angle of the films. This behaviour can be explained by the presence of polar groups present in the mucilage powder. Films without and with fibre presented similar values of water contact angle $\left(37.12^{\circ}-39.88^{\circ}\right)$, showing that the presence of the fibres does not affect the surface hydrophobicity of the films.

Jouki et al. [22] reported values of $48.53^{\circ}$ and $76.65^{\circ}$ in films with mucilages and with the addition of glycerol in concentrations ranging between $25 \%$ and $50 \%$.

Regarding WS, results showed that the control film and films with mucilage are entirely soluble in water. However, it was observed that the films without fibre were soluble after $1 \mathrm{~h}$, and those with fibres only reach total solubility after $3 \mathrm{~h}$. González-Sandoval et al. [13] obtained solubility values ranged from $81.3 \%$ to $91.0 \%$ for films with mucilages from Opuntia spp., while Beigomi et al. [25] obtained solubility values ranged between $46.40 \%$ and $54.63 \%$ for films with mucilages extracted from 
Dracocephalum moldavica. These differences can be explained by the differences in the polymer matrix when different types of mucilages are used.

\subsection{Water Vapour Permeability (WVP)}

Table 2 shows that the WVP values of the control films and films with mucilages are statistically different $(p<0.05)$. The incorporation of mucilages led to an increase of WVP, being the films without fibre those with higher WVP values. Results showed that the presence of the fibres (Viwf and Copwf) resulted in films with lower WVP when compared with films without fibre (Viwf and Copwf). The results show that the size of the fibres and composition of mucilage can influence the polymeric network decreasing the water vapour permeability.

The values are in agreement with those presented by González-Sandoval et al. [13] that obtained values of 1.63 to $8.40 \times 10^{-11} \mathrm{~g}(\mathrm{~m} \cdot \mathrm{s} \cdot \mathrm{Pa})^{-1}$ for films produced with mucilage from nopal. The main differences obtained by these authors are justified by the incorporation of additives and the different concentrations of mucilages used in their production.

\subsection{Mechanical Properties}

Young's modulus (YM), tensile strength (TS) and elongation-at-break (EB) of the films are presented in Table 3. The control film presented the higher values in all the properties, and are similar to some values of TS and YM values obtained for films with mucilage. The control film presents a very compact structure (as shown by SEM) and the incorporation of mucilage with fibres and other constituents interfere with their structure resulting in a decline of their mechanical properties. Among films with mucilage, the films with Viwf, Copwf and Copwtf showed similar YM values $(6.56,4.83$ and $5.13 \mathrm{MPa}$, respectively) and EB values lower than $10 \%$. However, the influence of fibres in the films with mucilage from Cop is clear, where the presence of the fibre decreases the values of TS and EB to $3.34 \pm 1.71 \mathrm{MPa}$ and $0.89 \% \pm 0.20 \%$, respectively.

Table 3. Tensile strength (TS), elongation at break (EB) and young's modulus (YM) of Copena F1 without fibre (Copwtf), Copena F1 with fibre (Copwf), Villanueva without fibre (Viwtf) and Villanueva with fibre (Viwf) films.

\begin{tabular}{cccc}
\hline Film Samples & TS (MPa) & EB (\%) & YM (MPa) \\
\hline Control & $21.11 \pm 3.95 \mathrm{a}$ & $9.57 \pm 2.51 \mathrm{a}$ & $6.78 \pm 1.56 \mathrm{ab}$ \\
Copwtf & $11.07 \pm 2.92 \mathrm{~b}$ & $2.91 \pm 0.64 \mathrm{~b}$ & $5.13 \pm 0.90 \mathrm{a}$ \\
Copwf & $3.34 \pm 1.71 \mathrm{c}$ & $0.89 \pm 0.20 \mathrm{c}$ & $4.83 \pm 1.44 \mathrm{a}$ \\
Viwtf & $16.11 \pm 2.76 \mathrm{ab}$ & $2.33 \pm 0.32 \mathrm{~b}$ & $8.41 \pm 0.68 \mathrm{~b}$ \\
Viwf & $14.75 \pm 8.66 \mathrm{a}$ & $2.60 \pm 0.88 \mathrm{~b}$ & $6.56 \pm 2.65 \mathrm{ab}$
\end{tabular}

Values reported are the mean $\pm \mathrm{sd}$. Different letters $(\mathrm{a}-\mathrm{d})$ in the same column indicate a statistically significant difference $(p<0.05)$.

The values are in agreement with the work of Espino-Díaz et al. [29] that used mucilage with plasticizer and obtained values of $0.95 \mathrm{MPa}$ to TS and $14.99 \%$ to EB. Gheribi et al. [15] produced films of mucilage with glycerol and other polyols, and also found a TS higher than $1 \mathrm{MPa}$, however they presented EB values greater than $60 \%$. The EB values obtained by Gheribi et al. [15] can be explained by the amount of plasticizer used, where high amounts of plasticizer lead typically to high EB values.

\subsection{X-ray Diffraction (XRD)}

Figure 3 shows the XRD spectra of the films. In general, all the films with mucilage exhibited the same peaks and in a similar position. However, the films with Copwtf and Viwtf showed the highest intensity compared to films with fibres.

The diffractogram of the film control shows one small peak in $2 \theta=15.5^{\circ}$. This signal is related to pectin and its crystalline structure. Pectin frequently presents two signals at $2 \theta, 12^{\circ}$ and $21.6^{\circ}$, and they 
can appear as a shoulder or peak that indicate if the sample has an amorphous or crystalline structure, respectively [37]. However, in this case, the mixture with a plasticizer (glycerol) changed the position of the first peak and made the second signal disappear [26]. However, the first peak increased with added mucilage with fibres.

In the case of the Copwtf and Viwtf, films showed two intensity peaks, approximately, in $2 \theta=24.5^{\circ}$ and $30^{\circ}$, and two small peaks in $36^{\circ}$ and $38^{\circ} 2 \theta$. The peaks $2 \theta=24.5^{\circ}$ and $38^{\circ}$ can be related to calcium oxalates $\left(\mathrm{C}_{2} \mathrm{CaO}_{4} \mathrm{H}_{2} \mathrm{O}\right)$ that is the major crystalline component found in nopal powders. Some works also related the peak in $2 \theta=15.5^{\circ}$ with the presence of the calcium oxalates. Therefore, this can explain the increase of intensity of the peak in $2 \theta=15.5^{\circ}$ when mucilage was added $[9,38]$. Concerning the peaks $2 \theta=30^{\circ}$ and $36^{\circ}$, these were related to the presence of calcium carbonate as calcite $\left(\mathrm{CaCO}_{3}\right)$ and potassium peroxydiphosphate $\left(\mathrm{K}_{4} \mathrm{P}_{2} \mathrm{O}_{8}\right)$, respectively. The peak in $2 \theta=30^{\circ}$ can also be related to the presence of calcium hydride $\left(\mathrm{CaH}_{2}\right)$. The presence of the calcium carbonate can be one advantage for the application of these films as coatings and in the edible films industry because calcium is a good component for the human body. Therefore, this fact can be important for using of the nopal mucilage in the food packaging [39].

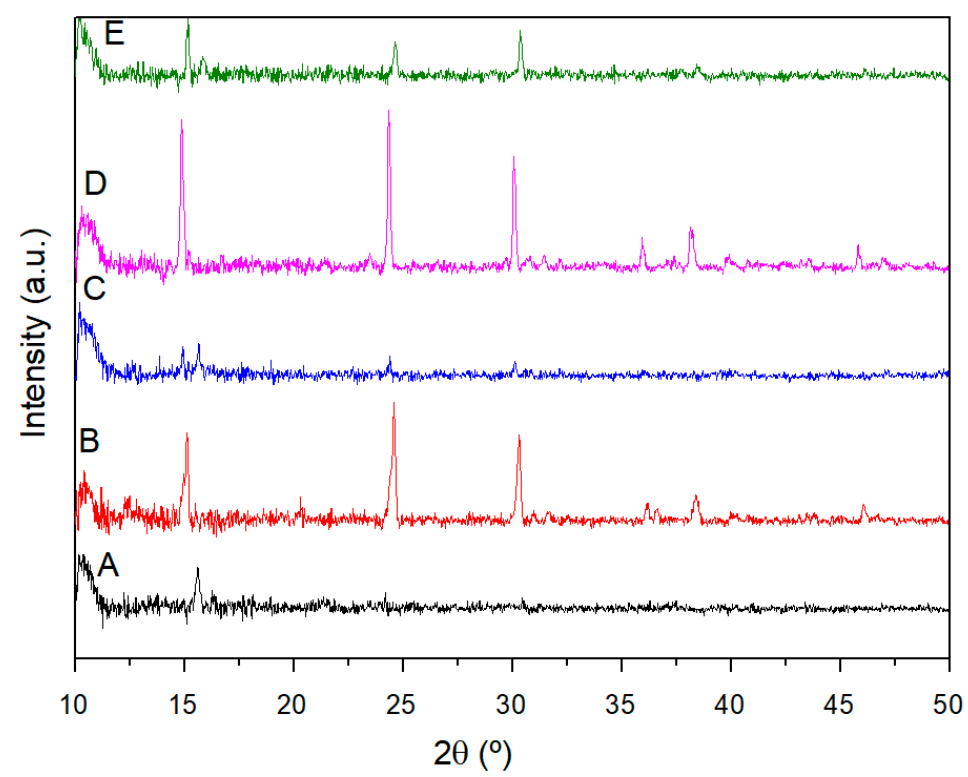

Figure 3. X-ray diffraction (XRD) patterns of films. (A) Control, (B) Copena F1 without fibre (Copwtf), (C) Copena F1 with fibre (Copwf), (D) Villanueva without fibre (Viwtf) and (E) Villanueva with fibre (Viwf).

\subsection{Fourier-Transform Infrared Spectroscopy}

Figure 4 shows FTIR spectra of the control film and films with mucilage. In general, all the films exhibited similar behaviour even with control film. The incorporation of mucilage of Copena and Villanueva in film formulation did not change the spectrum when compared to the control film. Moreover, the intensity of bands was also unchanged, so it can be suggested that no chemical interactions occur between pectin, glycerol and mucilage. However, it is important to mention that the distribution of fibres and some components can be heterogeneously distributed in the film matrix and it is possible that some changes cannot be identified by the ATR-FTIR methodology.

The broad band in the range $3000-3500 \mathrm{~cm}^{-1}$ relates to hydrogen bonding $(-\mathrm{OH})$ of the polysaccharide chains, glycerol and water molecules [40]. Another band was displayed in the range $2900-2700 \mathrm{~cm}^{-1}$, due to methoxyl groups $\left(\mathrm{CH}_{3} \mathrm{O}-\right)$ present in mucilage and the $\mathrm{C}-\mathrm{H}$ stretch of pectin structure [39]. The spectra also exhibited the typical response of pectin at 1735 and $1605 \mathrm{~cm}^{-1}$ corresponds to the carbonyl group $(\mathrm{C}=\mathrm{O})$ and carboxylate groups (COO-), respectively [41]. 
The alpha configuration of sugar in the mucilage was located at the wavelength of $724 \mathrm{~cm}^{-1}$, which coincides with the reports of Cai et al. [42].

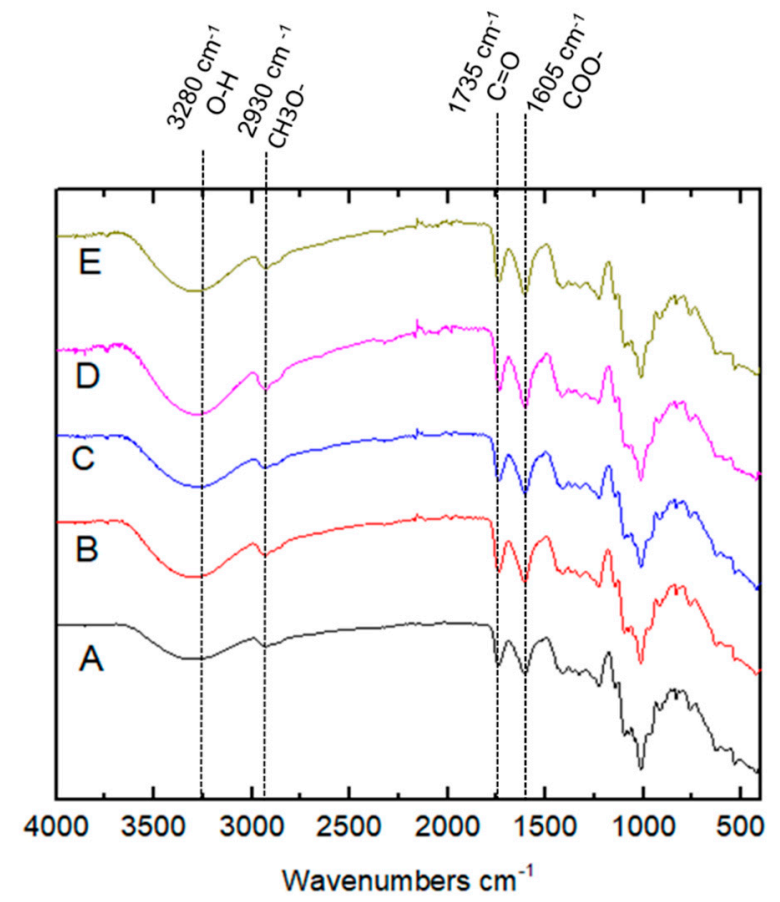

Figure 4. Fourier transform infrared (FTIR) spectrum of films. (A) Control, (B) Copena F1 without fibre (Copwtf), (C) Copena F1 with fibre (Copwf), (D) Villanueva without fibre (Viwtf) and (E) Villanueva with fibre (Viwf).

\subsection{Thermogravimetric Analysis (TGA)}

TGA was used to evaluate the thermal stability of the mucilage films. All TGA and differential thermal analysis (DTA) curves (Figure 5) exhibited similar behaviour of mass loss with two main phenomena. The first weight loss happened between 25 to $150{ }^{\circ} \mathrm{C}$ and was related to the evaporation of water molecules in the films. The second event happened in a range $150-325^{\circ} \mathrm{C}$ and was associated the decomposition of polysaccharides, namely pectin and nopal mucilage, because in this range of temperature a higher loss of weight for all samples was observed. Finally, a quasi-constant loss was observed for high temperatures.

For control film, in the first phenomenon, was detected a higher weight loss (25\%) when compared with the other films studied. This behaviour is related to the water evaporation present in the film matrix. For films with mucilages was observed a lower weight loss event. In the case of Copwtf and Viwtf they presented similar behaviour with weight loss values around $11 \%$ while for films with mucilage with fibre the values were below $7 \%$.

In the second phenomenon, all the films presented a similar behaviour, with the loss weight of approx. $50 \%$ and a maximum temperature of decomposition detected between 213 and $218{ }^{\circ} \mathrm{C}$. A third phenomenon was identified at around $310^{\circ} \mathrm{C}$ for films with mucilage; this phenomenon corresponds to the decomposition of some nopal mucilage constituents [41]. The residual mass at the end of the analysis was $14 \%-16 \%$ for control film and $25 \%-30 \%$ for mucilage films, which is explained by the inorganic compounds present in the mucilage. These values are similar to those reported by El Achaby et al. [43], Mujtaba et al. [44] and Sucheta et al. [45]. 

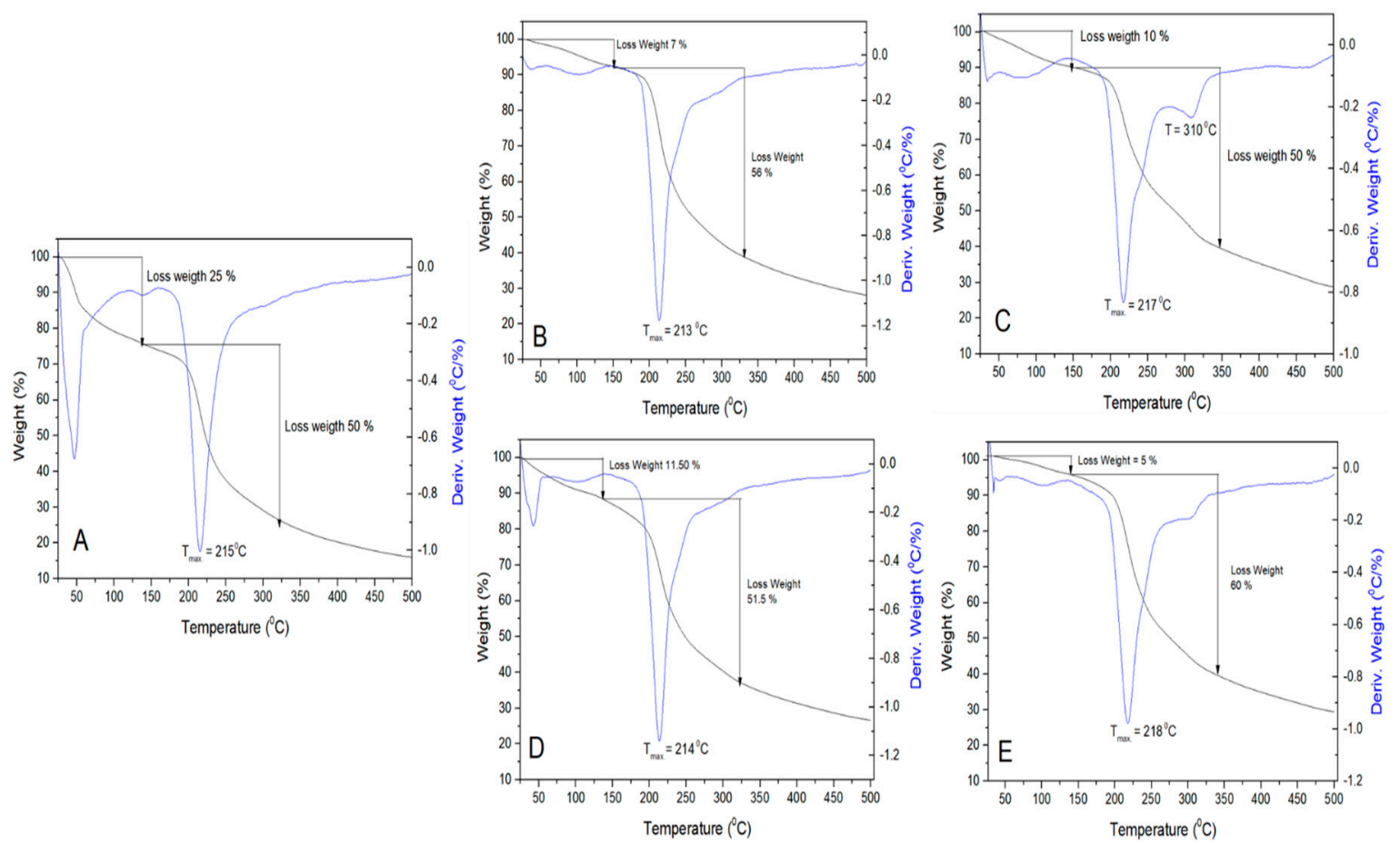

Figure 5. Thermogravimetric analysis (TGA) and differential thermal analysis (DTA) curves of films. (A) Control, (B) Copena F1 without fibre (Copwtf), (C) Copena F1 with fibre (Copwf), (D) Villanueva without fibre (Viwtf) and (E) Villanueva with fibre (Viwf).

\section{Conclusions}

Pectin-based films with nopal mucilage using two species: Copena F1 and Villanueva with and without fibres were successfully produced by the casting method. Results showed that mucilage (without and with fibres) from hydroponic nopal could be used to produce edible films with a good processability.

The presence of mucilage changed most of the films' properties. Overall, the pectin-based films without mucilage presented the best physical properties; however, in some cases, the values were close to those obtained for the films with mucilage. FTIR showed similar signals in terms of frequency and intensity for all the films and did not show any chemical modification. Taking into account all the measured properties, it can be said that the films where Villanueva mucilage with fibres (Viwf) were added were those with the best properties when compared with their counterparts to which mucilage was added.

This work provides a good view of how various sources of mucilage with and without fibres can influence films' behaviour. Taking into account the results obtained in this study, it can be said that the mucilage is suitable for incorporation in films and, therefore, can be used in the films' matrix as a source of bioactive compounds.

Author Contributions: Conceptualization, B.L.-S., A.G.A, R.R. and M.A.C.; Methodology, B.L.-S., A.G.A. and M.A.C.; Validation, B.L.-S., A.G.A, R.R. and M.A.C.; Formal Analysis, B.L.-S., A.G.A, R.R. and M.A.C.; Investigation, B.L.-S., A.G.A.; Resources, R.R., G.C.G.M.-Á., H.R.-F., L.M.P. and M.A.C.; Data Curation, B.L.-S. and A.G.A.; Writing-Original Draft Preparation, B.L.-S.; Writing-Review and Editing, B.L.-S., A.G.A., R.R. and M.A.C.; Supervision, G.C.G.M.-Á., H.R.-F., A.G.A, L.M.P., R.R. and M.A.C. All authors have read and agreed to the published version of the manuscript.

Funding: The authors thank to CONACYT-México, and CONACYT-CONAFOR 2018-1-B-65769 for the financing granted to carry out this project.

Acknowledgments: They also thank Sara Magali Cruz Zamudio for the English revision of the manuscript.

Conflicts of Interest: The authors declare no conflict of interest. 


\section{References}

1. Costa, M.J.; Marques, A.M.; Pastrana, L.M.; Teixeira, J.A.; Sillankorva, S.M.; Cerqueira, M.A. Physicochemical properties of alginate-based films: Effect of ionic crosslinking and mannuronic and guluronic acid ratio. Food Hydrocoll. 2018, 81, 442-448. [CrossRef]

2. Kraśniewska, K.; Pobiega, K.; Gniewosz, M. Pullulan-biopolymer with potential for use as food packaging. Int. J. Food Eng. 2019, 15. [CrossRef]

3. Cerqueira, M.A.; Bourbon, A.I.; Pinheiro, A.C.; Martins, J.T.; Souza, B.W.S.; Teixeira, J.A.; Vicente, A.A. Galactomannans use in the development of edible films/coatings for food applications. Trends Food Sci. Technol. 2011, 22, 662-671. [CrossRef]

4. Mellinas, C.; Ramos, M.; Jim, A. Recent trends in the use of pectin from agro-waste residues as a natural-based. biopolymer for food packaging applications. Materials 2020, 13, 673. [CrossRef]

5. Mohamed, S.A.A.; El-Sakhawy, M.; El-Sakhawy, M.A.-M. Polysaccharides, protein and lipid-based natural edible films in food packaging: A review. Carbohydr. Polym. 2020, 238, 116178. [CrossRef]

6. Dhanapal, A.; Rajamani, L.; Banu, M. Edible films from polysaccharides. Food Sci. Qual. Manag. 2012, 3, 9-18.

7. FAO Versión resumida. Futuro Agric. Aliment. 2017, 44. [CrossRef]

8. Behbahani, B.A.; Imani Fooladi, A.A. Shirazi balangu (Lallemantia royleana) seed mucilage: Chemical composition, molecular weight, biological activity and its evaluation as edible coating on beefs. Int. J. Biol. Macromol. 2018, 114, 882-889. [CrossRef]

9. Contreras-Padilla, M.; Pérez-Torrero, E.; Hernández-Urbiola, M.I.; Hernández-Quevedo, G.; del Real, A.; Rivera-Muñoz, E.M.; Rodríguez-García, M.E. Evaluation of oxalates and calcium in nopal pads (Opuntia ficus-indica var. redonda) at different maturity stages. J. Food Compos. Anal. 2011, 24, 38-43. [CrossRef]

10. Oliveira, N.L.; Rodrigues, A.A.; Oliveira Neves, I.C.; Teixeira Lago, A.M.; Borges, S.V.; de Resende, J.V. Development and characterization of biodegradable films based on Pereskia aculeata Miller mucilage. Ind. Crops Prod. 2019, 130, 499-510. [CrossRef]

11. Dick, M.; Dal Magro, L.; Rodrigues, R.C.; de Rios, A.O.; Flôres, S.H. Valorization of Opuntia monacantha (Willd.) Haw. cladodes to obtain a mucilage with hydrocolloid features: Physicochemical and functional performance. Int. J. Biol. Macromol. 2019, 123, 900-909. [CrossRef] [PubMed]

12. Mondragón-Jacobo, C.; González, S.P. El Nopal (Opuntia spp.) Como Forraje; Food and Agriculture Organization: Rome, Italy, 2003.

13. Sandoval, D.C.G.; Sosa, B.L.; Martínez-Ávila, G.C.G.; Fuentes, H.R.; Abarca, V.H.A.; Rojas, R. Formulation and characterization of edible films based on organic mucilage from Mexican Opuntia ficus-indica. Coatings 2019, 9. [CrossRef]

14. Willats, W.G.; Knox, J.P.; Mikkelsen, J.D. Pectin: New insights into an old polymer are starting to gel. Trends Food Sci. Technol. 2006, 17, 97-104. [CrossRef]

15. Gheribi, R.; Puchot, L.; Verge, P.; Jaoued-Grayaa, N.; Mezni, M.; Habibi, Y.; Khwaldia, K. Development of plasticized edible films from Opuntia ficus-indica mucilage: A comparative study of various polyol plasticizers. Carbohydr. Polym. 2018, 190, 204-211. [CrossRef]

16. Torres, L.; Gumecindo, C.; Bautista, E.; Gómez, Y. Opuntia ficus-indica mucilage and edible chitosan biofilms including brassica olearacea extract for extending the shell-life of capsicum annuum var serrano. Asian Res. J. Agric. 2018, 8, 1-9. [CrossRef]

17. Del-Valle, V.; Hernández-Muñoz, P.; Guarda, A.; Galotto, M.J. Development of a cactus-mucilage edible coating (Opuntia ficus indica) and its application to extend strawberry (Fragaria ananassa) shelf-life. Food Chem. 2005, 91, 751-756. [CrossRef]

18. Treviño-Garza, M.Z.; García, S.; Heredia, N.; Alanís-Guzmán, M.G.; Arévalo-Niño, K. Layer-by-layer edible coatings based on mucilages, pullulan and chitosan and its effect on quality and preservation of fresh-cut pineapple (Ananas comosus). Postharvest Biol. Technol. 2017, 128, 63-75. [CrossRef]

19. Ganesan, A.R.; Shanmugam, M.; Palaniappan, S.; Rajauria, G. Development of edible film from Acanthophora spicifera: Structural, rheological and functional properties. Food Biosci. 2018, 23, 121-128. [CrossRef]

20. Allegra, A.; Inglese, P.; Sortino, G.; Settanni, L.; Todaro, A.; Liguori, G. The influence of Opuntia ficus-indica mucilage edible coating on the quality of "Hayward" kiwifruit slices. Postharvest Biol. Technol. 2016, 120, 45-51. [CrossRef] 
21. Cortés-Camargo, S.; Acuña-Avila, P.E.; Rodríguez-Huezo, M.E.; Román-Guerrero, A.; Varela-Guerrero, V.; Pérez-Alonso, C. Effect of chia mucilage addition on oxidation and release kinetics of lemon essential oil microencapsulated using mesquite gum-Chia mucilage mixtures. Food Res. Int. 2019, 116, 1010-1019. [CrossRef]

22. Jouki, M.; Mortazavi, S.A.; Yazdi, F.T.; Koocheki, A.; Khazaei, N. Use of quince seed mucilage edible films containing natural preservatives to enhance physico-chemical quality of rainbow trout fillets during cold storage. Food Sci. Hum. Wellness 2014, 3, 65-72. [CrossRef]

23. Allegra, A.; Sortino, G.; Inglese, P.; Settanni, L.; Todaro, A.; Gallotta, A. The effectiveness of Opuntia ficus-indica mucilage edible coating on post-harvest maintenance of 'Dottato' fig (Ficus carica L.) fruit. Food Packag. Shelf Life 2017, 12, 135-141. [CrossRef]

24. Soukoulis, C.; Gaiani, C.; Hoffmann, L. Plant seed mucilage as emerging biopolymer in food industry applications. Curr. Opin. Food Sci. 2018, 22, 28-42. [CrossRef]

25. Beigomi, M.; Mohsenzadeh, M.; Salari, A. Characterization of a novel biodegradable edible film obtained from Dracocephalum moldavica seed mucilage. Int. J. Biol. Macromol. 2018, 108, 874-883. [CrossRef]

26. Sadeghi-Varkani, A.; Emam-Djomeh, Z.; Askari, G. Physicochemical and microstructural properties of a novel edible film synthesized from Balangu seed mucilage. Int. J. Biol. Macromol. 2018, 108, 1110-1119. [CrossRef]

27. Luo, M.; Cao, Y.; Wang, W.; Chen, X.; Cai, J.; Wang, L.; Xiao, J. Sustained-release antimicrobial gelatin film: Effect of chia mucilage on physicochemical and antimicrobial properties. Food Hydrocoll. 2019, 87, 783-791. [CrossRef]

28. Rodríguez-González, S.; Martínez-Flores, H.E.; Chávez-Moreno, C.K.; Macías-Rodríguez, L.I.; Zavala-Mendoza, E.; Garnica-Romo, M.G.; Chacõn-García, L. Extraction and characterization of mucilage from wild species of opuntia. J. Food Process Eng. 2014, 37, 285-292. [CrossRef]

29. Espino-Díaz, M.; De Jesús Ornelas-Paz, J.; Martínez-Téllez, M.A.; Santillán, C.; Barbosa-Cánovas, G.V.; Zamudio-Flores, P.B.; Olivas, G.I. Development and characterization of edible films based on mucilage of Opuntia ficus-indica (L.). J. Food Sci. 2010, 75, 347-352. [CrossRef]

30. Martins, J.T.; Cerqueira, M.A.; Vicente, A.A. Influence of $\alpha$-tocopherol on physicochemical properties of chitosan-based films. Food Hydrocoll. 2012, 27, 220-227. [CrossRef]

31. Casariego, A.; Souza, B.W.S.; Cerqueira, M.A.; Teixeira, J.A.; Cruz, L.; Díaz, R.; Vicente, A.A. Chitosan/clay films' properties as affected by biopolymer and clay micro/nanoparticles' concentrations. Food Hydrocoll. 2009, 23, 1895-1902. [CrossRef]

32. ASTM E96: Standard Test Methods for Water Vapor Transmission of Materials; ASTM: West Conshohocken, PA, USA, 1995.

33. ASTM D 882-91: Standard Test Method for Tensile Properties of Thin Plastic Sheeting; ASTM: West Conshohocken, PA, USA, 1991.

34. Pereira, R.N.; Souza, B.W.S.; Cerqueira, M.A.; Teixeira, J.A.; Vicente, A.A. Effects of electric fields on protein unfolding and aggregation: Influence on edible films formation. Biomacromolecules 2010, 11, 2912-2918. [CrossRef]

35. Da Silva Oliveira, C.I.; Martinez-Martinez, D.; Al-Rjoub, A.; Rebouta, L.; Menezes, R.; Cunha, L. Development of a statistical method to help evaluating the transparency/opacity of decorative thin films. Appl. Surf. Sci. 2018, 438, 51-58. [CrossRef]

36. Lira-Vargas, A.A.; Joel, J.; Corrales-Garcia, E.; Valle-Guadarrama, S.; Beatriz Peña-Valdivia, C.; Trejo-Marquez, M.A.; Cantu, J.; Izcalli, C.; Mexico, M. Biopolymeric films based on cactus (Opuntia ficus-indica) mucilage incorporated with gelatin and beeswax. J. Prof. Assoc. Cactus 2014, 16, 51-70.

37. Lutz, R.; Aserin, A.; Wicker, L.; Garti, N. Structure and physical properties of pectins with block-wise distribution of carboxylic acid groups. Food Hydrocoll. 2009, 23, 786-794. [CrossRef]

38. Contreras-Padilla, M.; Rivera-Muñoz, E.M.; Gutiérrez-Cortez, E.; del López, A.R.; Rodríguez-García, M.E. Characterization of crystalline structures in Opuntia ficus-indica. J. Biol. Phys. 2015, 41, 99-112. [CrossRef]

39. Contreras-Padilla, M.; Rodríguez-García, M.E.; Gutiérrez-Cortez, E.; del Valderrama-Bravo, M.C.; Rojas-Molina, J.I.; Rivera-Muñoz, E.M. Physicochemical and rheological characterization of Opuntia ficus mucilage at three different maturity stages of cladode. Eur. Polym. J. 2016, 78, 226-234. [CrossRef] 
40. Vanitha Kumari, G.; Ananth, N.; Mathavan, T.A.; Jothi Rajan, M.A. Synthesis and characterization of folic acid conjugated silver/gold nanoparticles for biomedical applications. Mater. Today Proc. 2016, 3, 4215-4219. [CrossRef]

41. Guadarrama-Lezama, A.Y.; Castaño, J.; Velázquez, G.; Carrillo-Navas, H.; Alvarez-Ramírez, J. Effect of nopal mucilage addition on physical, barrier and mechanical properties of citric pectin-based films. J. Food Sci. Technol. 2018, 55, 3739-3748. [CrossRef]

42. Cai, W.; Gu, X.; Tang, J. Extraction, purification, and characterization of the polysaccharides from Opuntia milpa alta. Carbohydr. Polym. 2008, 71, 403-410. [CrossRef]

43. El Achaby, M.; El Miri, N.; Hannache, H.; Gmouh, S.; Ben youcef, H.; Aboulkas, A. Production of cellulose nanocrystals from vine shoots and their use for the development of nanocomposite materials. Int. J. Biol. Macromol. 2018, 117, 592-600. [CrossRef]

44. Mujtaba, M.; Akyuz, L.; Koc, B.; Kaya, M.; Ilk, S.; Cansaran-Duman, D.; Martinez, A.S.; Cakmak, Y.S.; Labidi, J.; Boufi, S. Novel, multifunctional mucilage composite films incorporated with cellulose nanofibers. Food Hydrocoll. 2019, 89, 20-28. [CrossRef]

45. Chaturvedi, K.; Sharma, N.; Yadav, S.K. Composite edible coatings from commercial pectin, corn flour and beetroot powder minimize post-harvest decay, reduces ripening and improves sensory liking of tomatoes. Int. J. Biol. Macromol. 2019, 133, 284-293. [CrossRef]

(C) 2020 by the authors. Licensee MDPI, Basel, Switzerland. This article is an open access article distributed under the terms and conditions of the Creative Commons Attribution (CC BY) license (http://creativecommons.org/licenses/by/4.0/). 